\title{
Zoning-Based System of New Students Admission Policy
}

\author{
Rahmawati Rasinan', Sugiarto², Matin3 \\ DOI: 10.35445/alishlah.v13i2. 782
}

\begin{tabular}{l} 
Article Info \\
\hline Keywords: \\
Admission Policy; \\
Education; \\
Zoning System
\end{tabular}

Kata kunci:

Kebijakan Penerimaan; Pendidikan; Sistem Zonasi

\begin{abstract}
The zoning system in accepting new students is the government's effort to build quality, fair and equitable education. The purpose of the study was to obtain indepth information about the implementation of the zoning system in the acceptance of new students in Jakarta. This study used a descriptive qualitative tentative approach. Data were collected through interviews, observation and documentation. Data analysis techniques consist of data reduction, data presentation, and conclusion drawing/verification. The study results concluded that the implementation of the zoning system in the acceptance of new students was quite good and provided equal opportunities for all prospective students according to the right selection path. While the problems complained about are related to the internet network and also fraud committed by some people. However, the results of this study have an impact on improving the more equitable zoning system.
\end{abstract}

\begin{abstract}
Abstrak
Sistem zonasi dalam penerimaan peserta didik baru menjadi upaya pemerintah dalam membangun penyelenggaraan pendidikan berkualitas, adil dan merata. Tujuan penelitian adalah untuk mendapatkan informasi mendalam tentang implementasi sistem zonasi dalam penerimaan peserta didik baru di Jakarta. Penelitian ini menggunakan pendekatan deskriptif kualitatif tentatif. Data dikumpulkan melalui wawancara, observasi dan dokumentasi. Teknik analisis data terdiri dari rreduksi data, penyajian data, dan penarikan kesimpulan/verifikasi. Hasil penelitian menyimpulkan implementasi sistem zonasi dalam penerimaan peserta didik baru telah menunjukkan keadilan dalam penyebaran penerimaan siswa dan memberikan kesempatan yang sama bagi semua calon peserta didik sesuai dengan jalur seleksi yang tepat. Sedangkan permasalahan yang dikeluhkan terkait dengan jaringan internet dan juga kecurangan yang dilakukan sebagian orang. Namun, hasil penelitian ini berdampak pada perbaikan sistem zonasi yang lebih adil.
\end{abstract}

\footnotetext{
${ }^{1}$ Universitas Negeri Jakarta, Indonesia Email: rahmawatirasinan@gmail.com

${ }^{2}$ Universitas Negeri Jakarta, Indonesia Email: rahmawatirasinan@gmail.com 3 Universitas Negeri Jakarta, Indonesia Email: rahmawatirasinan@gmail.com
} 


\section{INTRODUCTION}

Equitable education implies equality and justice, where every citizen has the same opportunities and rights in obtaining access to decent and quality education. It means that all schoolage residents can get the same educational opportunities. This has been confirmed in Law Number 20 of 2003 concerning the National Education System, in article 5 and 11 paragraphs (1) and (2). To realize educational equity efforts, the Ministry of Education and Culture has issued an education policy through the Regulation of the Minister of Education and Culture Number 14 of 2018 concerning Admission of New Students for Kindergarten, Elementary, Middle and High School levels or vocational education, which is equivalent to the zoning system, as regulated in article 16, schools are obliged to accept prospective students who are domiciled in the radius of the nearest zone from the school based on the address on the family card. This policy is called the zoning system (Jia \& Ericson, 2017). Nevertheless, it faced the pros and cons of the zoning system (Ariyanto \& Chamidah, 2021).

Previously, the implementation of the selection of new student admissions in public schools was based on the results of national exam scores, thus creating a gap between schools (Anjarwati, 2020). The government creates excellent schools, where the schools are filled with students who have an above-average level of intelligence, have high-quality education staff, have adequate facilities and infrastructure and have complete facilities, which support the learning process in schools. It is considered a role model for other schools in various regions. This system forms a paradigm in society that excellent public schools are favorite schools, which are dominantly filled by students (i) who have high grades (achievements) or from groups who have certain financial resources. Furthermore, it is not a new thing if the government through the Department of Education and Culture makes superior schools a top priority, such as; improvement of facilities and infrastructure, the addition of adequate facilities, training for educators, as well as providing access to participate in various competitions at the Regional, National and International levels (Bintoro, 2018).

This situation, of course, creates a wide gap, thus creating 'casualization and 'discrimination' for state schools labeled as not superior. It creates injustice and inequality in society. Therefore, the government issued a new student admission policy with a zoning system to eliminate the community paradigm regarding superior (favorite) and non-favorite schools. It became one of the strategies to accelerate the distribution of quality education. The zoning system allows students to get the same access and quality of education reasonably (Ibrahim et al., 2021; Jia \& Ericson, 2017). Zoning policies can also reduce the burden of education costs in the community, especially transportation costs. In the zoning system, it is regulated that schools run by local governments are required to accept prospective students who are domiciled in the radius of the nearest zone from the school, at least $90 \%$ of the total number of students accepted. However, the zoning system carried out online has not been as expected (Hardiono et al., 2020). Indonesian people disagree with accepting the zoning system because there are more negative opinions than positive opinions (Ariyanto \& Chamidah, 2021). However, the zoning system for admitting new students in Surabaya has been assessed according to the ISO/IEC 25010 quality standard (Sekarini et al., 2020). In Sidoarjo Regency, the zoning system for new student admissions has been innovated by modifying the Education Office's technical instructions (Pradipta et al., 2020). Meanwhile, in Bandung, the zoning system has shown relatively good effectiveness in increasing the distribution of education quality (Hoerudin, 2019). A web-based new admissions information system can have the ability to provide convenience for parents of new students in terms of getting all information about new student admissions and carrying out the online registration process flow (Cahyono et al., 2019). Even though in its implementation, the zoning system still faces various problems. However, the gap of study with the previous research is evaluating of zoning system in new students admissions that have been done online. It has a different concept in new students' admission. 
As for the various problems that arise from the implementation of new student admissions from parents' complaints about the zoning system, namely: (1) Rejecting the zoning system policy, (2) State High Schools are minimal and uneven in distribution, (3) Questioning the zoning quota, (4) Inappropriate measurement of the distance from home to school to the detriment of prospective students, (5) Allegations of domicile manipulation and transfer of Family Cards, (6) Allegations of cheating and non-transparency in the process of admitting new students to announcements, (7) regions using grades The National Examination is not pure zoning so that prospective students whose homes are close to the school but are not accepted because of low National Examination scores, (8) Technical problems during registration, and (9) Regional Technical Guidelines do not comply with the Regulation of the Ministry of Education and Culture.

Therefore, this research was conducted to get the result of implementing a zoning system in new student admissions. In addition, this research can be useful in overcoming fraud in the zoning system, such as the existence of illegal Family Cards and buying and selling seats in the implementation of the selection of new student admissions at schools. Even the fraud is allegedly carried out systematically by irresponsible persons who become threats from objective, accountable, transparent, non-discriminatory, and fair admissions for new students.

This research was carried out to know the views of the East Jakarta State Senior High School principal on the implementation of the New Student Admissions selection according to zoning, which includes planning, organizing, implementing, and reporting.

\section{METHODS}

This study used a descriptive qualitative tentative approach (Creswell \& Creswell, 2018) to obtain research data using qualitative data collection procedures, namely through interviews, observation, and documentation. At first, the researchers used the interview method using an online questionnaire through the google form application. However, the responses from the informants were less responsive, so the researchers used the face-to-face interview method. The participants involved in this study were the school principal $(\mathrm{N}=10)$. Data were taken from 10 State Senior High Schools in East Jakarta. Ten schools were taken from 10 sub-districts that have the same characteristics in the new student admission system. The sampling technique used for school sampling is non-probability sampling. The data analysis technique used in this study is the Miles and Huberman model (Miles \& Huberman, 1994). Activities in the analysis are carried out continuously and take place continuously until data is considered credible or saturated. Activities in data analysis are data reduction, data display, and conclusion drawing/verification. The researcher used a data validity test which included test credibility (internal validity), transferability (external validity), dependability (reliability), and confirmability.

\section{FINDINGS AND DISCUSSION}

New Student Admission for the DKI Jakarta Province zoning involves schools, the Education Office, the Indonesian Child Protection Commission Community, non-governmental organizations, stakeholders and education experts, and the DKI Jakarta provincial government in determining policies for implementing procedures of New Student Admission. The DKI Jakarta Provincial Government issued Governor Regulation Number 32 of 2021 concerning Technical Instructions for Admission of New Students for the 2021-2022 Academic Year. As it is known, during the COVID-19 pandemic situation, the entire process of New Student Admission is carried out from home online. The principle of New Student Admission is objective, transparent and accountable. The paths used in the implementation of new student admissions are;

1. Achievements. This selection gives appreciation to children who have demonstrated academic and non-academic achievements.

2. Affirmations. This selection provides greater opportunities for children from poor families to access quality education and is subsidized by the Government. 
3. Zoning. This selection provides opportunities for children who live within the zoning area that has been determined by taking into account the distribution of schools, data on the domicile distribution of prospective students, and the capacity of the school's capacity which is adjusted to the availability of the number of school-age children at each level in the area.

4. Transfer of duties of parents and children of teachers. This selection provides opportunities for children from families whose parents have changed jobs and for children of teachers who want to go to school where their parents work.

\section{Planning of New Students Admission}

Based on the results of the perception analysis from several school principals, it can be concluded that the admission of new students this year has been very effective and takes into account the existing situation, especially during the Covid-19 pandemic through online registration from home and complying with health protocols according to government directions. The admission of new students in 2021 is also based on a fair legal basis to equalize education specifically in the DKI Jakarta area by providing the widest opportunity for children who are in DKI Jakarta or domiciled in DKI Jakarta to be able to study in DKI Jakarta.

The planning and preparation of new student admissions are based on the Regulation of the Ministry of Education and Culture, the Governor's Regulation, the Regulation of the Education Office, and the Head of the Service to produce Technical Instructions that have been made by the school in implementing the admission of new students based on the guidelines of the governor's special regulations for DKI Jakarta Number 32 of 2021 which is monitored directly by the Governor together with the DKI Jakarta Provincial Information and Statistics Communications and Statistics Office. In planning the policy for the implementation of new student admissions, all school principals understand the existing technical instructions because there is guidance in determining the policy rules for implementing new student admissions in 2021 by holding internal meetings several times from March to May 2021 between the principal and the Education office, stakeholders, community, non-governmental organizations, village heads, and also education experts.

The analysis of the principal's perception of planning for the admission of new students in 2021 is much better than last year because the DKI Jakarta Provincial Education Office organizes new student admissions to realize equality of opportunity for all citizens from all backgrounds. That way, the admission of new students can form state schools with a wide variety of students and a sense of cooperation to move forward together. Therefore, this policy is expected to form equal access to quality education for Jakarta children from all backgrounds. One of the striking differences in the requirements for admitting new students for Jakarta 2021 is that public or government-owned schools in the DKI Jakarta area may only accept students registered on the Family Card issued by the DKI Jakarta Civil Registry and Population Office.

The difference between new student admissions in Jakarta this year and 2020 is that nonJakarta residents are no longer allowed to register at Jakarta schools. There are restrictions on prospective students. As we know, last year, the admission of new students in Jakarta still provided a quota for students from outside the DKI Jakarta area of $5 \%$ of the student capacity accommodated by the school. However, for students registered on the DKI Jakarta Family Card but study outside DKI Jakarta, they can still take part in the admission of new Jakarta 2021 students by participating in pre-registration. The pre-registration process is carried out by completing the documents needed to be registered at the DKI Jakarta Provincial Education Office so that the student's name can be included in the Jakarta new student admission system.

\section{Organizing}

In organizing the admission of new students, each school forms a committee structure. It aims to simplify and expedite all forms of tasks, principals, and functions and responsibilities of each committee component and avoid work inequality. However, it still prioritizes the collective work 
principle of each component. Good organization of the implementation of new student admissions shows that every school carries out forming a new student admissions committee so that it can carry out new student admissions activities effectively and efficiently. The interviews with school principals stated that this year's new student admissions only involved a few teachers in the committee due to the COVID-19 situation. In addition, access to information and services is already digital-based that can be accessed at home. So the committee at the school monitors through the new student registration portal. In delegating tasks, the committees must have competence in using information systems to provide the best service for people who do not understand the technical instructions written in Governor Regulation Number 32 of 2021 on the DKI JAKARTA SIAP PPDB portal website. It means that the use of technology in education is very influential. Technological resources can be used as one of the new comprehensive evaluation methods to provide education (Lai \& Bower, 2019; Anglin \& Ley, 2002). There are various views on using technology for all educational activities (Salam et al., 2019). Digital technology is a tool to improve the quality of education (Zhao et al., 2021), and it is related to the 21-century context (van Laar et al., 2017).

\section{Implementation}

The implementation of the admission of new students in 2021 is by paying attention to the legal basis which follows the policy rules for accepting new students from home according to the rules of the central government and particular areas of Jakarta; 1) admission of new students is carried out online, 2) admission of new students from home, 3) admission of new students without gathering at school, and 4) admission of new students to prevent crowds and gatherings of prospective registrants and parents around the school environment. The mechanism for the admission of new students through the zoning route as stipulated in the Regulation of the Ministry of Education and Culture Number 1 of 2021 Article 12 paragraph (2) letter a consists of: a. Elementary school zoning line is at least $70 \%$ of the school's capacity; b. the junior high school zoning line is at least $50 \%$ of the school's capacity, and c. high school zoning line is at least $50 \%$ of the school's capacity.

\section{Reporting}

Reporting on the implementation of new student admissions in 2021 is carried out by the principal directly on the system's admission process. In addition, the results of the selection of new student admissions, monitoring and filling in the reporting sheets provided by the school supervisor and the education office through the google form link must be filled in regarding the new student admissions implementation process that takes place in schools. The monitoring activities are carried out for almost 1-2 months during new student admissions. There are two types of monitoring, namely monitoring from the supervisor with the package; Every two days, they come directly or through groups, are given a questionnaire by the supervisor and must be filled in, and sometimes for the supervisor is to visit the school when the admission of new students is running. Then monitoring from the Education Sub-Department through questionnaires is usually 1 or 2 times in the middle of the new student admissions process.

Furthermore, monitoring from the principal to the education office is usually done using a google form, official report, integrity pact or manual report. The school principal does it in collaboration with the committee providing daily reports and the results of the implementation of each new student admission selection path that takes place by writing down the services performed and evidence of the results of student admissions at school by filling out the google form sheet provided by the supervisor education authorities. Reporting is carried out at least once and daily reporting by uploading a new student admissions report file on the website or on the google form provided by the education office and supervisor with instruments that must be filled in and filled in on the conditions of new student admissions at that time.

Some of the obstacles found in the process of accepting new students were system errors so that many parents of prospective students could not register on the first day of registration. This 
causes high anxiety in parents of prospective applicants because one of the criteria for new students' admission is the time to register, which means that the speed of time in the registration process is not relevant to be a requirement to be accepted as a new student at school. When the SIAP ONLINE portal network experienced problems, then the Education Office implemented system improvements at the communication and information service department to minimize complaints from the public, especially parents of prospective students. The Positive Side of the Implementation of New Student Admissions Zoning: 1) Provide access for children around the school without value barriers, 2) Especially for Jakarta, it will reduce the level of traffic congestion because children can go to school by walking or cycling, and 3) Creating equal distribution of education quality in state schools. The new student admissions information system was built to handle everything related to the new student admissions process (Sekarini et al., 2020). It used a technology system. Web-based admissions information systems can have the ability to provide convenience for parents of new students in terms of getting all information (Cahyono et al., 2019). Using the re-used oriented concept, the student admission system was developed by adding, editing, and deleting requirements based on the current policy (Fissalma \& Ajie, 2019).

\section{CONCLUSION}

The study results conclude that the process of admitting new students to the zoning system in Jakarta in 2021 has been very effective because the implementation has referred to the applicable legal basis. The planning process to reporting is carried out through the collaboration of all parties involved in education provision. The problem that often arises is a system error due to the network. However, the school and the relevant education office immediately coordinated the matter to repair the network. The school also conveys information to prospective students' parents so that they do not feel anxious about the registration time. In addition, the zoning selection pathway system has provided many benefits for the community in obtaining a proper education and equal opportunities for all prospective students to apply to quality schools. That is, the zoning system builds equal distribution of education without having to be guided by values. The various selection pathways also provide fair opportunities for prospective students because everyone can adjust to applying to schools.

This research is still limited to the analysis of the zoning system in the acceptance of new students aimed at system evaluation. Therefore, this research can still be developed for further research. An in-depth study can be carried out to develop a new student acceptance model with a fair zoning system for outstanding students who cannot enter the best school areas. In addition, this research also has an impact on changing the new student admission system that is adapted to the context of needs according to the results of the evaluation

\section{REFERENCES}

Anglin, G. J., \& Ley, K. (2002). Trends and issues in instructional design and technology. Educational Technology Research and Development, 50(4), 67-71. https://doi.org/10.1007/bfo2504986

Anjarwati, S. (2020). Implementation of School Zonation System Policy (Study on the Problematics of New Student Admission Systems in Blitar City). In Prosiding ICoISSE (Vol. 1, Issue 1). http://conference.loupiasconference.org/index.php/ICoISSE/article/view/38

Ariyanto, R. A., \& Chamidah, N. (2021). Sentiment Analysis for Zoning System Admission Policy Using Support Vector Machine and Naive Bayes Methods. Journal of Physics: Conference Series, 1776(1), 12058. https://doi.org/10.1088/1742-6596/1776/1/012058

Bintoro, R. F. A. (2018). Persepsi masyarakat terhadap implementasi kebijakan zonasi sekolah dalam penerimaan peserta didik baru (ppdb) tingkat sma tahun ajaran 2017/2018 di kota samarinda. Jurnal riset pembangunan, 1(1), 48-57. https://doi.org/10.36087/JRP.V1I1.26

Cahyono, A., Pramono, B., \& Oganda, F. P. (2019). Design of Information System in Admission of New Students Based on Web in SMK Al Amanah. Aptisi Transactions on Management (ATM), 3(2), 159-167. https://doi.org/10.33050/atm.v3i2.1034 
Creswell, J. W., \& Creswell, J. D. (2018). Research Design: Qualitative, Quantitative, and Mixed Methods Approaches Fifth Edition. SAGE Publications Inc.

Fissalma, H., \& Ajie, H. (2019). Design and Development of Student Admission System in the State University of Jakarta. KnE Social Sciences, 3(12), 92. https://doi.org/10.18502/kss.v3i12.4076

Hardiono, H., Umar, M. A., \& Hidyantari, E. (2020). Zonation System Policy Implementation in the Admission of New Students in the City of Surabaya, East Java, Indonesia. The International $\begin{array}{llll}\text { Journal of } \quad \text { Business Management, } & \text { 8(12). }\end{array}$ https://doi.org/10.24940/theijbm/2020/v8/i12/bm2012-003

Hoerudin, C. W. (2019). Evaluation Of New Student Admission Policy Based On Zonation System In Bandung City. JISPO Jurnal Ilmu Sosial Dan Ilmu Politik, 9(2), 351-361. https://doi.org/10.15575/JISPO.V9I2.5483

Ibrahim, W., Tahir, A., Wahyuni, F. I., Bina, S., \& Gorontalo, T. (2021). The Effectiveness Of The Implementation Of The New Student Admissions Policy Through The Zoning System At The Education And Culture Office Of Gorontalo Regency. In Jurnal Ilmu Manajemen dan Bisnis (Vol. 9, Issue 1). https://journals.ubmg.ac.id/index.php/JIMB/article/view/169

Jia, Q., \& Ericson, D. P. (2017). Equity and access to higher education in China: Lessons from the human province for university admissions policy. International Journal of Educational Development, 52, 97-110. https://doi.org/10.1016/j.ijedudev.2016.10.011

Lai, J. W. M., \& Bower, M. (2019). How is the use of technology in education evaluated? A systematic $\begin{array}{llll}\text { review. Computers } \quad \& \quad \text { Education, } & \text { 133, 27-42. }\end{array}$ https://doi.org/10.1016/J.COMPEDU.2019.01.010

Miles, M. B., \& Huberman, A. M. (1994). Qualitative Data Analysis; An Expanded Sourcebook. Sage Publication.

Pradipta, R. F., Dewantoro, D. A., \& Purnamawati, F. (2020). Admission System for New Students: Study of Multi Sites in Special School. 335-338. https://doi.org/10.2991/assehr.k.201112.058

Salam, M., Awang Iskandar, D. N., Ibrahim, D. H. A., \& Farooq, M. S. (2019). Technology integration in service-learning pedagogy: A holistic framework. Telematics and Informatics, 38, 257-273. https://doi.org/10.1016/j.tele.2019.02.002

Sekarini, D., Alfiani, F. S., \& Rochimah, S. (2020). Security Characteristic Evaluation of New Students Admission Information System Based on ISO/IEC 25010 Quality Standard. ICITEE $202 O$ - Proceedings of the 12th International Conference on Information Technology and Electrical Engineering, 120-124. https://doi.org/10.1109/ICITEE49829.2020.9271756

van Laar, E., van Deursen, A. J. A. M., van Dijk, J. A. G. M., \& de Haan, J. (2017). The relation between 21st-century skills and digital skills: A systematic literature review. Computers in Human Behavior, 72, 577-588. https://doi.org/10.1016/j.chb.2017.03.010

Zhao, Y., Pinto Llorente, A. M., \& Sánchez Gómez, M. C. (2021). Digital competence in higher education research: A systematic literature review. Computers and Education, 168, 104212. https://doi.org/10.1016/j.compedu.2021.104212 